\title{
Socio Economical Effects of Migration in Geographical Migration of Bathore
}

\author{
Msc. Evelina Rina \\ Ministry of Interio, General Directorate of Police \\ Email : evelinarina@yahoo.com
}

Doi:10.5901/ajis.2014.v3n3p209

\begin{abstract}
After years 1990 the peripheral area of Tirana was affected by a massive interior migration, a fast, abusive and uncontrolled by the state structures. This fact found the local authoritative unprepared to arrange such an enormous number of people so the consequences were a lot and consecutive, serious, a part of them irreparable and with negative effects. We are in front of a wild urbanization which except others has misused and consumed the physical geographical space. And this as a result of a very fast pace of development happened to this area at the beginning of years '90 which still continues though not in the same rhythm. This because of fast developments this area had at the beginning of years ' 90 which still continue today though not at the same pace. The real representative of these big changes is Bathore which has lived an overall development of a high rhythm transforming from a village completely unknown to a phenomena that represents the uncontrolled and problematic urbanization of the main Albanian cities. Even the nowadays developments of this area form one more argument that testify for developments between suburb and urban zones of this area. The large immigration to this area, related to the lack of legislation allowed the population of this area and its construction without applying the minimum infrastructure requirements and out of any rule. This chaotic establishment was followed by social-economic and environmental problems which are still worrying for this analyzed area. Bathore is a bad example of misusing geographical area for which professional surveys, debates, multidisciplinary discussions must be made on purpose that such developments will not be repeated in the future. These surveys are not totally absent and some of them are even associated with interventions in improvement of situation in one part of Bathore, aiming in continue its integration as a whole into urban area. This paper aims to analyze the actual demographic, social-economical and environmental developments not only to make evident the changes of urban and rural changes in comparative view. This comparative analysis attempts to identify problems but also highlight the features of urban and rural development by identifying future trends that are particularly important in planning development strategies.
\end{abstract}

Keywords:Interior migration, negative effects, urban and rural spaces, development strategy etc.

\section{Bathore, on Focus of Developments}

Bathorja is comprised in the Municipality of Kamez. Regarding the extension we can say that its surface is approximately 362 ha. Bathore has nearly 30 thousands of inhabitants, a population that started after years 1992. Up to recent years, no one knew anything about Bathore. All that we knew was that Bathore was a small village in the suburb of Tirana in its north-west side. It had arable lands, vineyards, and fruit trees which was part of green crown of Tirana city. During the period 1992-1994 it was spoken a lot about it because of informal settlements phenomena of a very large population transferred from remote northen and northeast areas of the country and of their settlement in Bathore and beyond.

At the beginning the inhabitants were placed spontaneously building huts and small houses, while today many of them are replace with villas of 2-3 floors. But outside these villas the situation is different, problematic. Each of incomer occupied a piece of land and built according to his financial capacity he had at the start or which he did later. The incomers had also the same mentality that "let's leave the areas of hill-mountanous areas, and later let's hope for better".

Encouraged from chaos of political changes and from total lack of vision and control of authorities of that time about the disciplining of that immigration people of these areas took the initiative to be settled near the big cities and especially near Tirana, for a better life. They escaped to avoid famine. The opinion that a big city like Tirana would give them the chances for a better life, for a more secure life for themselves and their children, made them abandon their places and transfer near the capital city. The incomers, mainly from north area are settled in the northeast of Tirana, near the Agricultural Institute of Kamez.

Today in Bathore live 6502 families or better say about 30 thousands inhabitants (registered in the Office of Civil States of the Municipality of Kamez are 28012 inhabitants). Many of them came at the beginning of years' 90 , the others followed very fast and today the place where it was only a very big field is densely populated. Nearly all the incomers in this area are from northeast area of Albania (Tropojë, Kukës, Mat, Mirditë, Pukë etc), very poor areas, and economically backward because of natural phenomena not very favouring, as a result of isolation from mountainous terrain and lack of a developed road and telecommunication infrastructure. 
The fast demographic growth in the informal area of Bathore has caused a big problem: the chaotic urban development. The main reasons of this situation are:

$>$ The previous communist regime did not allow the free population movement and the most part of population lived in its rural areas. The free population movement as a right pronounced after year 1990 brought the migration of thousands of people who abandoned the north part of the country where it was impossible to provide living and they were directed to the urban areas, mainly in Tirana and to its suburbs for a better future for themselves and their children. As a consequence whole areas were created with informal houses.

$>$ The existence of free public areas was a chance for the incomers to be established and therefore create the informal areas.

$>$ The government was not able to react to this situation and respond to the requirements of inhabitants for public services.

$>$ The great flux of incomers from various northern reagions formed a very homogenous community. Many inhabitants do not know anything about the way of living in an urban area and they tent to use the same traditional and conservative way of living, especially with the mentality for women and girls. Living is very conditioned on close interests of the family and the attempts to improve it in accordance with common community interests are very little. The inherited mindset focused only to taking care of house, people, to the personal court, impedes the integration, the development of all infrastructure elements, etc. The largest coming of population happened during the period of 1993-1996. Actually the migrating flow to Bathore is reduced. The reason why it has fallen down may be one of the following:

- Lack of free areas as the old land owners were interested and they took the unoccupied parts.

- The government's attitude during last years against informality has concluded in:

- Demolishing irregular constructions.

- Requiring legal registration

- Approval of banning laws

After year 2004, $7 \%$ of constructions have been pulled down in the areas surveyed in the context of urbanization of the area in legalization process.

\subsection{Social-economic problems}

Bathore inside the region of Kamez is an area that is already mentioned like the symbol of community inclusion in urban development. It is divided in seven areas of development like Bathore 1, 2, 3 and 4 which are known like the area of Urban Bathore and 5, 6 and 7 like the area of Rural Bathore. Actually state has proclaimed that the areas 5, 6, and 7 will be considered as urban sections of Bathore that means all of it. Throuh self-management and self-construction it is formed the process of a gradual improvement of sheltering bringing the arrangement of conditions of their houses, their extension, especially vertically. In general, the families have been successful regarding building houses, especially separated from one another. The data indicate that the surface of the area of Urban Bathore is 250 ha. All Bathore is located in a surface of $362 \mathrm{ha}$. This surface is divided in such land sizes that vary from 100 to $1500 \mathrm{~m}^{2}$. In this division the first group is the one of families who owns $400-500 \mathrm{~m}^{2}$. About $15 \%$ of land plot are of size $700-1500 \mathrm{~m}^{2}$ and only $6 \%$ with a surface of $90-150 \mathrm{~m}^{2}$.

Table 1. Number of houses built up to year 2000 and during the period 2000-2012

\begin{tabular}{|l|c|c|}
\hline \multicolumn{1}{|c|}{ Number of floors } & No. of houses built in year 2000 & No. of houses built in period 2000- 2012 \\
\hline 1 floor & $90 \%$ & $64 \%$ \\
\hline 2 floors & $8 \%$ & $24 \%$ \\
\hline 3 floors and more & $2 \%$ & $12 \%$ \\
\hline
\end{tabular}

\section{Resource: City Planning office, Municipality of Kamez}

It is evident in the above table the higher percentage consists in houses of one floor. Their majority are built by blocks. If we make a simple analysis of the situation from 2000 to 2009 the percentage of one floor houses is lowered and the percentage of two floors houses is increased from $8 \%$ in 2000 to $24 \%$ (two floors houses) in 2009. A sensitive growth of $10 \%$ has also happened with the constructions with three and more floors. This growth in percentage of houses in vertical direction has happened as a consequence of: 
- Lack of lands to build

- Increase of incomes of the inhabitants (especially by migrating)

- Their tendency to have bigger houses and more living commodity.

- As a result of living two or more couples under the same roof.

The price of land per $\mathrm{m} 2$ has been increasing during years. So in 1997 in the area of Bathore the land prices was 50-300 All/m2, while in year 2002 was 2500-4000 All/m2.

The prices of selling houses in the period 1997-2002 have been trebling and after this period there is an increase of prices and not fall, regardless the fact of not being with the high pace of period'97-2002 (City planning of the Municipality of Kamez, Study by Co-Plan in cooperation with World Bank). All the land of urban Bathore is registered by the cadastral office of the Municipality of Kamez. The majority of families in Bathore have also another property especially in the place of where they come. Their large migration belongs to the begining of years 1990 time of great political changes where many of them inspired and encouraged the population movement.

Chart 1. Proceeding of population number in Bathore, 1997-2009

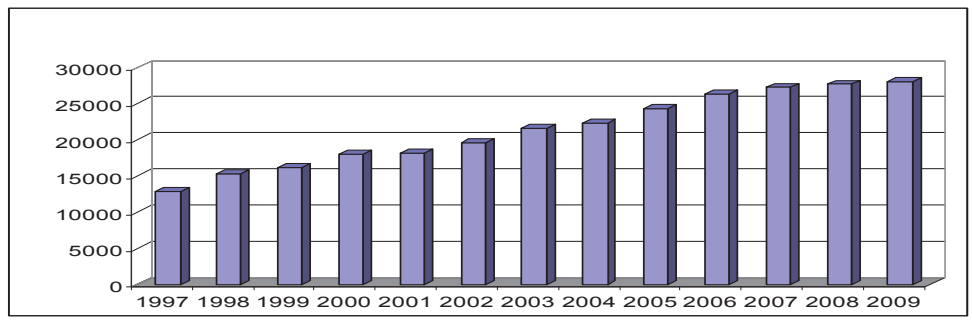

For years 1992-1996 there are no data about the population of Bathore as the first official statistics of registered population start in 1997 with a population number of 2812 inhabitants and a number of families of 2952.

The progress of families' number follows the same line as the progress of population with the same sensitive increase of families' number year by year. In 2005-2006 it is noted the greates increase of this number with about 1279 families. This is realted not only to the number of great incoming of population and with population registration in these years but according to the Office of Civil Status of Bathore during 2005-2006 the number of requests for family division has been very high at about 421 requests.

Most dwellers are of northern country origin. Their origin is mainly from the distant rural areas and the relations are established on their blood and regional relations, so since at the beginning they created stable relations with each other. $39 \%$ of interviewees expressed that they had come with their families and did not know anyone there before while $61 \%$ expressed that have come down here helped by their kin who were established before in Bathore.

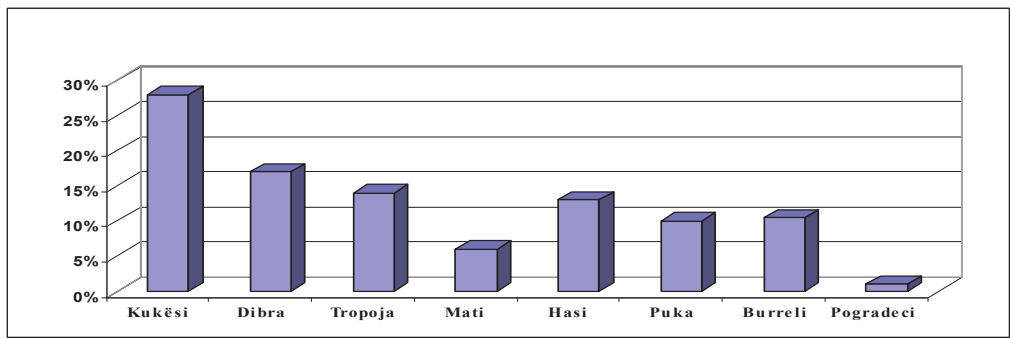

Chart 2. Geography of coming population by origin

The greatest percentage of population established in Bathore is from Kukes followed by the population coming from Diber, Tropoje and Has. From the interviews made it is also noted a population coming from the rural part of Pogradec though in a very low percentage (1\%).

Basing on a survey, in the following table are shown the reasons of population coming to Bathore. The economic reasons and the hope for better chances of employment are the main reasons of this large flux of population after year 
1991 to the area of Bathore.

Table 2. Reasons of migration in percentage, 2012

\begin{tabular}{|l|c|}
\hline \multicolumn{1}{|c|}{ Reasons } & Percentage \\
\hline Economical reasons & $82 \%$ \\
\hline Free land/ shelter & $7 \%$ \\
\hline children/ relatives / climate & $11 \%$ \\
\hline
\end{tabular}

About $40 \%$ of incomers for economic reasons are established in Bathore for better possibilities of employment being close to Tirana. $5 \%$ are located because of free land and only $2 \%$ for housing as they have lost their lands and houses in the places from where they come for different reasons like: irregular ownership; loss of house as a consequence flooding from the Lake of Fierze etc. For a better education of their children and other social motives stay $9 \%$ e interviewees. An interview from Zalli Gjoshit (Burrel) says: "there is no school, no hospital and 9 months under snow. It is obviously because of children, I had to leave". $2 \%$ of interviewees have come to join their familiars. The most of them have come later after year 1997.

The following table gives us the percentage of population by age. It is noted a high percentage of population of young age ( $35 \%$ group of age $0-15$ years old).

Table 3. Percentage of population by group of ages

\begin{tabular}{|c|c|}
\hline Cohort & Percentage \\
\hline $\mathbf{0}-15$ & $35 \%$ \\
\hline $\mathbf{1 5 - 5 5}$ & $58 \%$ \\
\hline Mbi 55 & $7 \%$ \\
\hline
\end{tabular}

Resource: INSTAT "Bulletin of Economic-Social Indexes for Tirana, Year 2012"

It is evident that this is a population of a very young age and vital. Years later these group of ages will enter in the age interval that gets employed, but it will not be easy for such a great manpower to find a job which is the biggest problem of this area.

Only $10 \%$ of manpower is employed in formal sector, while $45 \%$ ask for a seasonal job in the city of Tirana. The collapse that has clamped the producing capacities of all the country is the main reason of this situation. On the other side the low educational level of youngsters, who represent the significant weight of population has made them employed as arm workers, in construction, or to immigrate in neighbor countries (which is the main resource of incomes).

Regarding the employement the situation is like this:

Table 4. Employment status

\begin{tabular}{|c|c|c|c|c|}
\hline Regular job and full time & Part time and partial job & Immigrants & Retired & Unemployed \\
\hline $8 \%$ & $19 \%$ & $5 \%$ & $16 \%$ & $52 \%$ \\
\hline
\end{tabular}

Resource: Ministry of Labor, Social Affairs and Equal Opportunities, 2012

Professionally speaking, men in their majority have the profession of farmer and builder, but there is also a part of them employed as electricians, mechanics, plumbers, tireman. While women, most of them are housewives, are employed or selfemployed as handcrafts. In Bathore it is spread the handy made works. It is in process the establishment of a market to trade the articles made by women, but it has remained on hands of individuals, not gathered together yet. This project would help the common collective work of women to produce and sell their works and extend the borders of market. However, it is necessary to raise a market to sell these products of goods which creats not only a possibility of employment but conserves the Albanian traditions of their areas of origin.

A part of dwellers have attended or attend professional courses, for example girls for tailor, hairdresser or boys for electricians, mechanics, plumbers, construction.

The land is fit in the area of rural Bathore and people in genera have knowledge how to cultivate vegetables, bread farm animals as a tradition of places from where they come. The demand for vegetables production and consumption is 
also very high. This would stimulate them to deal with cultivation of many agricultural cultures, helping them to be selfemployed. If they can produce in large quantities this would serve to trade them and to raise the level of incomes, which would reduce the import of productions from beyond the area or from abroad. It is obviously needed the aid of state to reach this.

\subsection{Dwelling and social structure}

Bathore as already mentioned above is divided in urban and rural parts which are in antithesis with each other. The rural part has very difficult living conditions because even the most vital elements are absent like drinking water, sewerage canal digging; septic wells used with an extreme pollution level etc. The unique alternative for drinking water by inhabitants is using water wells which are of very low hygienic standard.

In 1996 only $3.8 \%$ of families in Bathore Pilot have been supplied with drinking water through illegal connections.

This area was selected in the project referred as Bathore Pilot because of:

- Vicinity with the main road (national) Tirana- Shkodër

- The existence of a better infrastructure network than that of the other parts of Bathore

- The active activity of organizations of community basis

- The positive experience reached in previous projects in implementation of physical and social infrastructure It results from the data that from all the population of Bathore only $45 \%$ of families are connected with the waterworks network and they are water supplied (here it is included all Bathore 1, 2, 3 and a part of Bathore 4). Is is still very high the percentage of families water supplied by water wells ( $45 \%$ of families) and it goes here the Rural Bathore $5,6,7$ and a small number of families from Bathore 4. The highest percentage of families that take water from neighbors, belong to Bathore 4 being near Bathore 1 and 3. The percentage of families who buy water is very small because of insufficient incomes to provide water in such way.

Regarding the sewrage canal digging the situation is still problematic.

In1997 almost 100\% of families use as sewerage the septic holes or connections with draining channels. While in 2002 after the construction of infrastructure 100\% in Bathore Pilot have connectections with sewrages channels, $75 \%$ in Bathore 2 and $85 \%$ in Bathore 3

But in Bathore 4, 5, 6 and 7 the situation is the same. To concern is the fact of using the draining system (draining channels) for discharging the sewrage in size of $13 \%$.

Another concern that slowly in collaboration with people is going towards solution is the supply of families with electric energy measures and engaging contracts with OSSH.

There is no road infrastructure to facilitate the interior connections. There are only some narrow passing roads for inhabitants what in bad weather conditions make the movement of people difficult.

A very big problem is the accumulation of wastes. The dwellers throw them around, burn or ditch them. A small number of families pay for removing wastes privately. In addition, another solution has been the depositions of waste along the river sides of Terkuze. Along its river valley, the piles of garbage accompany the river flow. The draining channels are often used as places to throw garbage, causing their blocking and in cases of high rainfalls they flood the surrounding houses and lands. It is not new the alarm given for water pollution which is used by the population. Though the cleaning of draining channels is made several times, the problem still continues to be present as long as the garbage management issue is still unsolved. The negative consequences of waste accumulation must be seen as a cost for a large number of inhabitants. Of course this has a cost but even the pollution of environment has a cost. In order to guarantee this kind of service the cost of expenses has to be covered. A creaging solution must be found in providing and maintaining services. For example, the cost of secondary infrastructure can be lowered as a result of contribution of inhabitants. It can be realized through an unpaid voluntary work, other suitable technological solutions can be found in favor of dwellers.

Waste incineration beside the unpaved roads and burning wood for heating during winter and for cook, the often use of grave machineries along the road of Zall-Herr, have increased the air impurity. The diseases of lungs have become normal in Bathore as it is reported in health centers, the diseases are related to polluted air and to the premises of houses built out of required standards. The building materials and structures are not of good quality. But the main reason for all mentioned is the low economic level the low educational and cultural level of inhabitants. 
Table 5. Classification of population according to education level

\begin{tabular}{|c|c|c|c|}
\hline 8 years education & High school education & Higher education & Without education \\
\hline $83 \%$ & $24 \%$ & $4 \%$ & $7 \%$ \\
\hline
\end{tabular}

Resources: INSTAT, 2012

As we see above we can say that the population of Bathore has a low educational leve. This significantly affects the employment of inhabitans in various sectors as they do not have the right formation.

Compared to the other urban ares the situation in Bathore is very alarming. The percentage of inahbitants with 8 years school is nearly twice higher than the urban areas of the country $83 \%$ to $43.8 \%$. What prevails is the low number of inhabitans with university formation. This situation is a big social problem for the present and future of this area.

The legalization process and its importance for a sustainable development. Most of new constructions were realized during its occupation of what was considered to be public. The first developments started close to the roads, the electric lines, the water lines etc. Usually who came first took a large part of land, which later was divided between families or sold. The most part of land around is occupied.

In case of Bathore the provision of several services has improved sensitively the living standard making a step forward towards the stable area development. Now Bathore is in a phase where except the initial mechanisms for development, the community associations are demanding from authorities the legal recognition of neighborhoods that constitute the construction of physical infrastructure and fulfillment of social services. The plan of urban development of Kamez enforces this process that means in general no existing house will be demolished and the illegal inhabitants will not be put out from the area with force. So at the same time we have the procedures of legalization first in the small areas taken as pilot (about $13 \mathrm{ha}$ ), also the measures being taken for infrastructure improvement. The development of Kamez or Bathore requires real planning forms and city planning regulations in order to enforce them and not making them only in written.

Regarding the problem of using land, there are measures to be taken to mitigate this problem like:

1- Improving the territory planning and adjusting. Revaluation of land use according to the purpose.

2- Legalization of constructions in conformity with the laws.

3- Their regrouping in a net of public buildings (flats) releasing gradually the lands occupied, and making them available to a future urban plan.

- Unification of construction types and of façade of their villas, in order to have a more harmonic and esthetic ensemble before the cacophony of placement and construction they actually present.

- Using the land efficaciously

- Improvement of land registration system

- Solving the ownership problems

Bathore in itself represents a known model of periurban developing areas characterized of the same problems and development situation.

\section{References}

Surveys

ALUIZNI , Various data about legalization

Municipality of Kamez, Forms of Agriculture Directorate

Municipality of Kamez, Forms of Regional Directorate of Waterworks Sewerage

INSTAT, "Registration of population and houses", April 2001

Ministry of Labor, Social Affaris and Equal Opportunities

Municipality of Kamez, Forms of Civil Status

Municipality of Kamez, Statistics bulletin 2009-2012

Municipality of Kamez, Forms of Educational Office

World Bank, "Financing, Effectiveness and Equality in Albanian Education"

INSTAT, Statistical Bulletin for Tirana, years 2010-2012

Educational office, Municipality of Kamez 